\title{
Analysis of the Effect of Corporate Governance Attributes and Disclosure Level on Firms’ Costs of Financing*
}

\author{
Raef Gouiaa \\ University of Québec in Outaouais, Québec, Canada \\ Daniel Zéghal \\ University of Ottawa, Ottawa, Canada
}

\begin{abstract}
The purpose of this article is to analyze the impact of corporate governance and disclosure policy on corporate financial performance by examining the combined effect of board characteristics and disclosure level on financing costs. The empirical analysis, conducted on a sample of 192 Canadian companies, generally shows the importance of board characteristics in determining the level of disclosure and firms' costs of financing. In particular, the results found indicate that boards whose characteristics meet the governance requirements that are associated with greater transparency in disclosure on governance attributes reduce the costs of financing of their companies by debt as well as by equity capital.
\end{abstract}

Keywords: board characteristics, disclosure level, cost of equity capital, cost of debt

\section{Introduction}

The recent financial crisis that hit the global economy and the scandals that affected several large companies in the world contributed to showing the importance of corporate governance and increasing the interest of researchers and policy-makers for thorough and detailed analyses on corporate governance and disclosure transparency. A review of the academic and professional managerial literature shows the importance of the board of directors in the corporate governance system; the board allows management to assist and control in the fulfillment of its mandate to protect the rights of shareholders and investors and consequently improve company value (Fama \& Jensen, 1983). However, the effectiveness of this governance mechanism in fulfilling its roles and functions largely depends on its characteristics (Harris \& Raviv, 2008). This research aims to associate board features, as the central mechanism of the governance system, to disclosure transparency concerning the level of information provided in the annual reports, in the analysis of changes in the cost of corporate financing. Board features are related to directors' independence, duality or separation of CEO and chairman functions, board size and operations, directors' financial motivations, their expertise and their experience, size, independence and meeting frequency of the audit committee and the representation of financial institutions and women on the board.

\footnotetext{
* Acknowledgements: We are very grateful for the support of the Foundation of University of Québec in Outaouais and CPA-Canada Accounting and Governance Research Centre.

Raef Gouiaa, Ph.D., professor of Accounting, University of Québec in Outaouais. Email: raef.gouiaa@uqo.ca.

Daniel Zéghal, Ph.D., FCGA, professor emeritus, Telfer School of Management, University of Ottawa.
} 
Our research differs from previous studies on several levels. First, this attention to the combined impact of board characteristics and transparency level on corporate financing costs is a relatively new concern from previous studies that have usually studied the separate effect of these governance characteristics on various other measures of financial performance. In addition, the detailed analysis of several board features allows a better understanding of the strategic and financial roles of the board in the corporate governance system. Finally, and compared to previous studies that have focused on close research questions, we can situate the contribution of our research on two levels. First, the majority of the previous studies have been limited to assessing the effect of the corporate governance characteristics on either the level of disclosure or financial performance without analyzing the combined effect of the two variables in explaining the financial performance. The divergence of previous studies' results analyzing the effect of corporate governance features on firm evaluation could be due to the fact that corporate governance characteristics do not determine directly business performance. Indeed, the mediating variable of disclosure transparency influences the impact of corporate governance attributes on firm value and performance. Second, this research analyzes disclosure transparency through the level of information provided on governance, ownership, and financial information in annual reports. It then allows examining the individual and combined effect of the various categories of information disclosed and their interactions in determining the corporate costs of financing.

The results reveal the importance of board characteristics in determining both the level of disclosure and the cost of corporate financing. These results also show the importance of the transparency level effect in the disclosure of the different categories of information studied and their interactions on financing costs. In particular, results from different analyses show that boards whose characteristics meet the requirements of good governance and who are associated with greater disclosure transparency on governance attributes can significantly reduce the costs of financing their companies. This article is organized as follows. The second section presents the theoretical framework of our research and the hypotheses to be tested. Methodological aspects are the subject of the third section, while the fourth section is devoted to the presentation and analysis of results. In the final section, we review the main results and contributions of this study.

\section{Theoretical Framework and Research Hypotheses}

\section{Transparency in Disclosure and Corporate Financing Costs}

Information disclosure tends to reduce the level of information asymmetry between managers and investors. The agency's theory considers the volume and content of the information disclosed as an effective way to reduce the costs of surveillance of directors by investors and creditors (Jensen \& Meckling, 1976). In a context of asymmetric information between external investors and managers, they have interest in reporting, through the content and the level of the information disclosure, to the financial market on their business profitability outlook to benefit better financing conditions and lower costs of capital. In addition, disclosure of information can reduce the search extent for private information and the transaction costs (Merton, 1987) and increase the liquidity of stocks (Diamond \& Verrecchia, 1991). Businesses need external funding resources to finance their investments and projects in an environment of uncertainty and lack of transparency. Thus, the disclosure policy appears as a mechanism that can reduce information asymmetry and lower the costs of corporate financing (Verrecchia, 1983). 
Subject to asymmetric information problems, shareholders and capital providers can neither directly observe the effort of leaders, nor know the true value of the business or the quality of management, thus creating agency costs, hazardous moral problems, and potentially adverse selection problems (Gompers, Ishii, \& Metrick, 2003). These situations result from agency risk that rational investors and lenders calculate the price in the form of cost of equity and cost of debt. In this context, a greater volume of information disclosed in annual reports reduces information asymmetry and facilitates access of the company to lower external financing costs (Botosan, 1997; Healy \& Palepu, 2001). Hence, we propose the following hypothesis:

H1: The level of information disclosure has a negative effect on financing costs by equity capital and debt as well as average cost of capital.

\section{Effect of Board Characteristics}

The board of directors is a central mechanism in the corporate governance system and plays an important role in determining the disclosure strategies, funding policies and therefore in determining the economic and financial performance of companies. The effectiveness of this governance mechanism essentially depends on its characteristics. Indeed, several empirical studies have highlighted the importance of certain board characteristics and its committees on its operations and effectiveness (De Andres, Azofra, \& Lopez, 2005; Coles, Daniel, \& Naveen, 2008; Gouiaa \& Zéghal, 2009). Hence, we design the following general hypothesis:

$\mathrm{H} 2$ : The boards whose characteristics meet the requirements of good governance have a positive effect on the level of information disclosure.

H3: The boards whose characteristics meet the requirements of good governance have a negative impact on financing costs.

Board composition. The role of the board is to provide an independent and effective control of management and make it accountable for its actions towards its shareholders. The effectiveness of this control largely depends on the percentage of independent directors on the board (De Andres et al., 2005). Indeed, the independent directors are more willing to ensure effective control and more transparent disclosure because they are not employees and they aspire to maintain their reputation (Beasley, 1996). Hence, we make the following hypothesis:

H2.1: Board independence has a positive effect on the level of information disclosed by the company.

Allowing better monitoring of accounting and financial processes, independent boards should promote a more transparent disclosure policy benefiting investors and creditors through a more reliable assessment and more effective control of the company (Adams \& Ferreira, 2007; Coles et al., 2008). Indeed, greater transparency will result in a lower estimate of the risk of default and reduced agency costs that will benefit the company in the form of lower financing costs. Hence, we propose the following hypothesis:

H3.1: Board independence has a negative effect on financing costs by equity capital and debt as well as average cost of capital.

Board size. The size of the board plays an important role in the directors' ability to control and supervise the accounting and financial processes (Pearce \& Zahra, 1992; Eisenberg, Sundgren, \& Wells, 1998). Indeed, the effectiveness of supervision performed by the board increases with its size due to the possibility of distributing the workload over a greater number of directors (Klein, 2002). In addition, larger boards allow better monitoring and are more effective in controlling by bringing greater expertise (Adams \& Mehran, 2002). Therefore, if larger boards are more efficient supervisors of accounting and financial processes, information users should benefit through a more transparent disclosure. Hence, we present the following hypothesis:

H2.2: The size of the board has a positive effect on the level of information disclosed by the company. 
Furthermore, better control of the financial reporting process, favored by larger boards, leads to a lower risk of information and a more reliable assessment of the company. Thus, larger boards should support the reduction of agency costs, resulting in reduced costs of financing by equity capital and debt. Hence, we make the following hypothesis:

H3.2: Board size has a negative effect on financing costs by equity capital and debt as well as average cost of capital.

Duality of CEO and chairman functions. Separating the chief executive and the chairman of the board means a greater independence of the board, because it avoids the concentration of power in a single individual who can dominate decision-making (Pearce \& Zahra, 1992). The structure separating the two functions enhances the independence of the board and makes it able to effectively control agency problems and avoid rooting strategies of leaders (Klock, Mansi, \& Maxwell, 2005). Thus, the duality of functions promotes the adoption of strategies that maximize managers' private benefits and limit the extent of information disclosure. Hence, we propose the following hypothesis:

H2.3: The duality of functions has a negative effect on the level of information disclosed by the company.

Reducing the disclosure transparency through limited voluntary disclosure, the duality of functions increases the premium risk that investors and creditors require to financing the company. Thus, the duality of functions could result in increased costs of financing for the business. Hence, we make the following hypothesis:

H3.3: The duality of functions has a positive effect on financing costs by equity capital and debt as well as the average cost of capital.

Audit committee composition. The audit committee plays an important role in ensuring greater disclosure transparency through communication of all relevant information to stakeholders (Beasley, 1996). The Blue Ribbon Committee Report (1999) indicates that the independent members of the audit committee are able to protect and ensure the efficiency of the reporting process and the reliability of accounting data. Independent committees are more likely to have longer meetings with the internal auditor, to meet privately with the external auditor, to examine in detail the program and the results of the internal audit (Raghunandan \& Rama, 2007) and thus promote a wider and more reliable disclosure. Hence, we make the following hypothesis:

H2.4: The independence of the audit committee has a positive effect on the level of information disclosed by the company.

Greater transparency disclosure provided by independent audit committees should help reduce company's financing costs by reducing the level of uncertainty regarding the reliability of financial information and consequently, the level of the estimated risk (Raghunandan \& Rama, 2007). Indeed, as risk and uncertainty levels are high, investors and creditors require higher risk premium to compensate them (Anderson, Mansi, \& Reeb, 2004). Hence, we propose the following hypothesis:

H3.4: The independence of the audit committee has a negative effect on financing costs by equity capital and debt as well as the average cost of capital.

Audit committee size. A review of the literature shows that larger audit committees are associated with more comprehensive disclosure by devoting more resources to overseeing the accounting and financial reporting process (Klein, 2002; Raghunandan \& Rama, 2007). Indeed, a smaller audit committee would have less time and resources to spend in monitoring the accounting and financial reporting process, in questioning of management and meetings with the internal control system personnel, translating into limited voluntary disclosure (Anderson et al., 2004). Hence, we make the following hypothesis: 
H2.5: The size of the audit committee has a positive effect on the level of disclosed information.

Improved disclosure transparency through complete and detailed accounting and financial information, and a broader level of voluntary disclosure favored by larger audit committees will result in better assessment of the company and its risks by shareholders and lenders (Lambert, Leuz, \& Verrecchia, 2007). Thus, an effective control by a larger audit committee should result in reducing financing costs by equity capital and debt. Hence, we make the following hypothesis:

H3.5: The size of the audit committee has a negative effect on financing costs by equity capital and debt as well as the average cost of capital.

The representation of financial institutions in the board of directors. The relationship between firms and financial institutions through the representation of the latter in their boards can improve the flow of information between the company and its creditors and increase, as a result, funding opportunities with these organizations (Kroszner \& Strahan, 2001). Indeed, the financial institution acting as a certification mechanism in the board reduces the information asymmetry between management and stakeholders by ensuring disclosure of reliable and non-manipulated information and covering all information necessary for decision-making (Alexandre \& Paquerot, 2000). Hence, we propose the following hypothesis:

H2.6: The representation of financial institutions in the board has a positive effect on the level of disclosed information.

Thus, representatives of financial institutions can limit managerial opportunism through better control of management actions and consequently reduce risks and agency costs faced by shareholders and lenders (Easley \& O’Hara, 2004). Accordingly, investors and creditors will demand a lower risk premium when granting funds to the company which should result in lower costs of equity capital and debt. Hence, we make the following hypothesis:

H3.6: The representation of financial institutions in the board has a negative effect on financing costs by equity capital and debt as well as the average cost of capital.

Directors' competence and expertise. The board of directors composed of competent and experienced members allows for an effective control of management actions and promotes effective decision-making. These directors promote the disclosure of more detailed information beyond the regulatory limits (Raghunandan \& Rama, 2007) and the disclosure of accounting information without manipulation within the exercise of their functions of controlling the accounting and financial process (Xie, Davidson, \& DaDalt, 2003; Francis, Nanda, \& Olsson, 2008). Hence, we propose the following hypothesis:

H2.7: The tenure of the board has a positive effect on the level of disclosed information.

Assuming that expertise and experience of directors (tenure) have a positive effect on disclosure transparency, board tenure is expected to reduce the company's financing costs by equity and debt. Indeed, boards composed of competent, experienced, and knowledgeable directors will allow better control of management and will promote effective decision-making, consequently reducing risks and agency costs for shareholders and creditors (Anderson et al., 2004; Coles et al., 2008). Hence, we propose the following hypothesis:

H3.7: Board tenure has a negative effect on financing costs by equity capital and debt as well as the average cost of capital. 
Board of directors and audit committee meeting frequency. The frequency of meetings of the board and its committees is determinant for their effectiveness in the exercise of their functions (Coles et al., 2008). Indeed, the increased number of board meetings as well as its overseeing committees, particularly the audit committee, is positively related to the quality of control on management and information disclosure (Vafeas, 1999). A higher frequency of meetings can promote a comprehensive monitoring and detailed examination of the accounting and financial reporting process. Hence, we propose the following hypothesis:

H2.8: The frequency of meetings of the board of directors and the audit committee has a positive effect on the level of disclosed information.

Since it allows strengthening the quality of control exercised by the board and its audit committee on the executives and the accounting and financial reporting process, the frequency of meetings of the board of directors and the audit committee allows reducing company financing costs through a reduction of risk and agency costs faced by shareholders and investors. Indeed, they see the boards and committees that meet more often as a signal that these governance mechanisms effectively perform their functions, which reduces risks of accounting manipulation and earnings management along with the risk of expropriation of private benefits by the executives (Harford, Mansi, \& Maxwell, 2008). Hence, we propose the following hypothesis:

H3.8: The frequency of meetings of the board and its audit committee has a negative impact on financing costs by equity capital and debt as well as the average cost of capital.

Women's representation on the board. In addition to their experience and different points of view, women bring new knowledge and contacts to the board for which relationships are the greatest assets (Adams \& Ferreira, 2009). Thus, the increased attendance of women on the board is supposed to improve its effectiveness in carrying out its functions of control and making the right decisions in favor of greater transparency through more extensive disclosure and comprehensive accounting and financial information, reflecting all the details without manipulation or adjustments. Hence, we propose the following hypothesis:

H2.9: The representation of women on the board has a positive effect on the level of information disclosure.

Improving disclosure transparency, boards with a higher representation of women should reduce funding costs by reducing the level of risk that creditors estimate before providing their funds to the firm. Indeed, when women are represented in the board, they will seek to prove to the other directors and the stakeholders that they are also competent in the discharge of their duties, making the board more effective in view of the creditors. Hence, we make the following hypothesis:

H3.9: The representation of women on the board has a negative effect on financing costs by equity capital and debt as well as the average cost of capital.

Financial motivations of directors. The financial motivations push to ensure long-term success of the company, especially when directors are involved in its capital (Yermack, 2004; K. Chen, Z. Chen, \& Wei, 2009). Indeed, the motivations of directors to perform their functions effectively are stronger when they are independent shareholders which would encourage them to improve the value of the company and consequently their assets (Jensen \& Meckling, 1976). Thus, independent directors who are shareholders are associated with greater oversight and more effective control of the reporting process which leads to a more extensive and well detailed disclosure. Hence, we present the hypothesis as follows:

H2.10: The percentage of capital held by the independent directors has a positive effect on the level of disclosed information. 
Assuming that the directors' financial incentives increase the transparency level through comprehensive disclosure, we expect that these incentives help reduce company funding costs by equity capital and debt. Indeed, these directors will be more attentive and more effective in ensuring a more transparent disclosure which meets the requirements of creditors and investors (Cremers \& Nair, 2005; Chen et al., 2009). Thus, they will face reduced risks and agency costs, which should result in lower financing costs. Hence, we present the following hypothesis:

H3.10: The percentage of capital held by the independent directors has a negative impact on financing costs by equity capital and debt as well as the average cost of capital.

\section{Combined Effect of Board Characteristics and Disclosure Level on Financing Costs}

The effect of board characteristics on the company's financing costs is influenced by the disclosure transparency. Indeed, a structure of the board supporting effective control of management and the accounting and financial reporting process provides a more transparent disclosure through a larger volume of information provided. Disclosure transparency, which allows for investors and creditors to better assess the company through comprehensive and detailed information, promotes a reduction of uncertainty and risk estimates, which leads to lower costs of financing by equity capital and debt.

However, a company that has a strong governance system and a board that meets the requirements of best governance practices, but does not provide detailed information on the quality of governance mechanisms in place, risks paying more for its financing resources. Indeed, external investors and creditors will not be aware of the quality of the governance mechanisms if there is no extensive and detailed disclosure not only on the accounting and financial data, but also on the structure of ownership, shareholder rights, and on the structure and process of the governance system, particularly about the board and its characteristics.

On one hand, shareholders and potential investors consider an effective board as a favorable signal to safeguard their interests. The boards meeting the requirements of good governance can reduce the risks and agency costs for shareholders. They also promote a more transparent disclosure through comprehensive and detailed information that allows to assess the company and its economic and financial performance and to estimate risk and future cash flows. Furthermore, an effective board acts as insurance to the creditors and lenders of the business by allowing better control of opportunistic behavior of managers and a more transparent disclosure. This leads to a better understanding and improved monitoring of the performance of the firm. Indeed, creditors rely on the data disclosed by the company to assess the risk of failure and the level of performance when granting credits to the company (Cremers \& Nair, 2005). A more transparent disclosure combined with an effective board reduces the risk premium required by lenders and investors in the granting of funds. This leads to lower financing costs for the company. Thus, changes in funding costs can be better explained through the simultaneous analysis of board characteristics and the level of disclosure. Hence, we present the fourth general hypothesis:

H4: Transparent disclosure combined with strong board characteristics significantly reduces financing costs.

\section{Methodology}

\section{Sample and Data Collection}

To test our hypothesis, we analyzed the 2010 annual reports of the companies belonging to the Canadian Index S\&P/TSX Composite: the main stock index on the Canadian stock market. Among the companies making up the index, we eliminated foreign companies and those operating in the financial sector (banking, insurance, 
etc.). They have been excluded from the sample because the accounting policies for this sector are very specific and quite different from those applicable to the non-financial sectors. This treatment is also justified by the fact that the restriction to non-financial corporations increases the homogeneity of the sample and improves the robustness and comparability of the results. In addition, the financial institutions' governance system is quite specific and different from that of non-financial companies (Macey \& O’Hara, 2003). We also excluded companies for which one of the variables was missing and foreign-owned companies subject to specific regulations, which reduced our final sample to a total of 192 companies listed on the Toronto Stock Exchange.

The data for this study, for fiscal year 2010, were collected from different databases. First, we collected the stock information from the Toronto Stock Exchange - Canadian Financial Markets Research Centre (TSE-CFMRC) database. Furthermore, the accounting and financial data and analyst forecasts were extracted from the database of Compustat Research Insight. Finally, data on the index of disclosure and corporate governance, as well as all data unavailable in the above databases were manually collected from company annual reports for the year 2010. These reports were downloaded from SEDAR's online database.

\section{Measurement of Dependent Variables: Financing Costs}

Cost of equity (COST_EQ). We use the ex-ante Easton's (2004) model to estimate the cost of equity. The Easton model is based on the estimation of abnormal earnings defined as current earnings of the period plus the profits of the reinvested dividends of the previous period less the projected normal profits based on profits last year. This model assumes that abnormal profits so defined persist in perpetuity. The choice of this model is justified on one hand, by its simplicity, since it does not require a lot of data, and on the other hand, by the superiority of methods which supports the growth of abnormal profits in estimating the cost of net capital notably for models including price-earnings growth (PEG) compared to other ex-ante estimate methods of financing costs. The cost of equity is determined using the following formula:

$$
r_{P E G}=\sqrt{\frac{E P S_{2}-E P S_{1}}{P_{\mathrm{o}}}}
$$

where $E P S_{1}$ and $E P S_{2}$ represent analysts' forecasts average earnings per share in the next two years; $P_{\mathrm{o}}$ represents the price share at the end of the current year. As part of the 2010 estimation of ex-ante equity costs, we use the forecast earnings per share of 2011 and 2012 extracted from the Institutional Brokers' Estimate System (I/B/E/S) database.

Cost of debt (COST_DEBT). The cost of debt is measured by the yield to maturity of the debt. This rate is the discount rate that equalizes the net price of the issue of borrowing expenses at the present value of all cash flows that the company must pay.

Weighted average cost of capital (AVG_CC). The weighted average cost of capital is obtained by weighing the cost of different sources of funding for their ratios in the capital structure of the firm (Blom \& Schauten, 2008). The weights relating to each source of funding are evaluated from the book values.

\section{Measurement of Explanatory Variables}

Disclosure level: Index of transparency and disclosure (TR_DISC). To measure the level of information disclosure, we use the T\&D index developed by S\&P by relying on the information that Canadian firms provide in their annual reports. The approach to rating items is dichotomous: the item's value is equal to 1 if the information is disclosed and 0 if otherwise. To ensure that the judgment of relevance is not biased, the 
entire annual report is read before any notation is made. The data for all of the 98 items that make up the T\&D index were extracted directly and manually from the 192 annual reports for the year 2010. The scores of different items are added and weighted in the same way to get the final score for each firm. The T\&D score for company $j$ is calculated as follows:

$$
\operatorname{SCORE}_{j}=\left(\sum_{i=1: N} X_{i j}\right) / N
$$

where $N$ is the total number of items that should be disclosed to company $j(N=98) ; X_{i j}$ is equal to 1 if item $i$ is disclosed for company $j$, and 0 if otherwise.

Data for the 98 items have not been weighted to reduce subjectivity (Ahmed \& Courtis, 1999). The 98 items are selected to represent the factors that are relevant in the analysis of financial disclosure, as well as non-financial governance. We consider the 98 attributes in three sub-categories using S\&P's classification scheme: shareholders rights (TD_SR); financial information (TD_FI); and board characteristics $\left(T D \_B R D\right)$.

Table 1

Variables Description and Anticipated Signs

\begin{tabular}{|c|c|c|c|}
\hline \multirow[b]{2}{*}{ Variable } & \multirow[b]{2}{*}{ Description } & \multicolumn{2}{|c|}{ Expected sign } \\
\hline & & \begin{tabular}{|l|} 
Costs of \\
financing
\end{tabular} & $\begin{array}{l}\text { Disclosure } \\
\text { level }\end{array}$ \\
\hline \multicolumn{4}{|c|}{ Explanatory variables } \\
\hline BRD_SIZE & Board size: Number of directors comprising the board of directors. & - & + \\
\hline$D U A L$ & $\begin{array}{l}\text { Duality or separation of CEO and chairman functions: Dummy variable that takes the } \\
\text { value of } 1 \text { when the CEO is also the chairman of the board (duality) and } 0 \text { if otherwise } \\
\text { (separation of functions). }\end{array}$ & + & - \\
\hline BRD_IND & \begin{tabular}{|l|} 
Board independence: Percentage of independent directors on the board. \\
\end{tabular} & - & + \\
\hline$A U D \_S I Z E$ & Audit committee size: Number of directors comprising the committee. & - & + \\
\hline$A U D \_I N D$ & $\begin{array}{l}\text { Audit committee independence: Percentage of independent directors on the audit } \\
\text { committee. }\end{array}$ & - & + \\
\hline FIN_MOTIV & $\begin{array}{l}\text { Financial motivations of independent directors: Percentage of capital held by the } \\
\text { independent directors. }\end{array}$ & - & + \\
\hline BRD_TEN & \begin{tabular}{|l|} 
Board tenure: Average operating time of directors in the board. \\
\end{tabular} & - & + \\
\hline$B R D \_F R E Q$ & Meeting frequency of the board: Number of meetings of the board of directors annually. & - & + \\
\hline$A C \_F R E Q$ & $\begin{array}{l}\text { Meeting frequency of audit committee: Number of meetings of the audit committee } \\
\text { annually. }\end{array}$ & - & + \\
\hline WOM_REP & $\begin{array}{l}\text { Representation of women on the board: Dummy variable that takes the value of } 1 \text { if one } \\
\text { or more women are represented in the board and } 0 \text { if otherwise. }\end{array}$ & - & + \\
\hline FI_REP & $\begin{array}{l}\text { Representation of financial institutions on the board: Dummy variable that takes the } \\
\text { value of } 1 \text { when there are representatives of financial institutions on the board of the } \\
\text { company and } 0 \text { if otherwise. }\end{array}$ & - & + \\
\hline \multicolumn{4}{|c|}{ Control variables } \\
\hline FRM_SIZE & Firm size: Logarithm of the book value of total assets. & - & + \\
\hline$R O A$ & Return on assets: Earnings before interest and taxes/total assets. & - & $+/-$ \\
\hline FIN_LEV & Financial leverage: Leverage ratio based on book values = total debt/total assets. & + & + \\
\hline$M B$ & $\begin{array}{l}\text { Market to book: Growth opportunities measured by the ratio: Market value of } \\
\text { equity/book value of equity. }\end{array}$ & & + \\
\hline$M U L T \_L I S T$ & $\begin{array}{l}\text { Multiple listing: Dummy variable that takes the value of } 1 \text { if the company is listed on } \\
\text { international markets and } 0 \text { if it is listed on the Toronto Stock Exchange only. }\end{array}$ & - & + \\
\hline VOLAT & $\begin{array}{l}\text { Volatility: Risk of the firm measured by the volatility of equity returns (standard } \\
\text { deviation of stock returns). }\end{array}$ & + & \\
\hline$I N D$ & $\begin{array}{l}\text { Industry: Measured by four dichotomous variables for the four main industries: IND1 } \\
\text { (energy), IND2 (materials), IND3 (manufactory), and IND4 (services). Each variable } \\
\text { takes the value of } 1 \text { if the firm belongs to the specific industry and } 0 \text { if otherwise. }\end{array}$ & $+/-$ & $+/-$ \\
\hline
\end{tabular}


Board characteristics. Features of the board investigated relate primarily to: the independence of directors; the duality of functions of the CEO and chairman of the board; the size and operation of the board; financial motivations of the directors, as well as their expertise and experience; size, independence, and frequency of meetings of the audit committee; and the representation of financial institutions and women on the board of directors. Measurements of all these characteristics are shown in Table 1.

Control variables. The features of the board are not the only factors that can influence the disclosure transparency and the costs of financing. The operational and financial characteristics related to firm size, financial performance, financial leverage, industry, risk level, multiple listing, and growth opportunities can also determine both the level of information provided and the costs of financing. The measurements of these variables and their expected effects are shown in Table 1 . All collected variables are winsorized to $1 \%$ to control extreme and aberrant values that may skew the results of subsequent regressions.

\section{Research Models}

In this study, we developed four regression models to test the validity of our assumptions. In the first two, we examine the effect of the disclosure level (TR_DISC Index and its three sub-components) on the costs of corporate financing.

$$
\begin{gathered}
C O S T_{-} E Q / C O S T_{-} D E B T / A V G_{-} C C=\beta_{0}+\beta_{1} T R_{-} D I S C+\beta_{2} F R M_{-} S I Z E+ \\
\beta_{3} F I N_{-} L E V+\beta_{4} R O A+\beta_{5} M U L T_{-} L I S T+\beta_{6} M B+\beta_{7} V O L A T+\beta_{8} I N D+\varepsilon \\
C O S T_{-} E Q / C O S T_{-} D E B T / A V G_{-} C C=\beta_{0}+\beta_{1} T D_{-} S R+\beta_{2} T D_{-} F I+ \\
\beta_{3} T D_{-} B R D+\beta_{4} F R M_{-} S I Z E+\beta_{5} F I N_{-} L E V+\beta_{6} R O A+ \\
\beta_{7} M U L T_{-} L I S T+\beta_{8} M B+\beta_{9} V O L A T+\beta_{10} I N D+\varepsilon
\end{gathered}
$$

In the third and fourth regression models, we analyze the effect of board characteristics on the disclosure level and the financing costs.

$$
\begin{aligned}
& T R_{-} D I S C=\beta_{0}+\beta_{1} B R D_{-} S I Z E+\beta_{2} B R D_{-} I N D+\beta_{3} D U A L+\beta_{4} A U D_{-} S I Z E \\
& +\beta_{5} A U D_{-} I N D+\beta_{6} F I N_{-} M O T I V+\beta_{7} B R D_{-} F R E Q+\beta_{8} A C_{-} F R E Q \\
& +\beta_{9} W O M_{-} R E P+\beta_{10} B R D_{-} T E N+\beta_{11} F I \_R E P+\beta_{12} F R M \_S I Z E+ \\
& \beta_{13} F I N_{-} L E V+\beta_{14} R O A+\beta_{15} M U L T \_L I S T+\beta_{16} M B+\beta_{17} I N D+\varepsilon \\
& C O S T_{-} E Q / C O S T \_D E B T / A V G_{-} C C=\beta_{0}+\beta_{1} B R D \_S I Z E+\beta_{2} B R D \_I N D+\beta_{3} D U A L+ \\
& \beta_{4} A U D_{-} S I Z E+\beta_{5} A U D_{-} I N D+\beta_{6} F I N_{-} M O T I V+\beta_{7} B R D_{-} F R E Q+\beta_{8} A C_{-} F R E Q+ \\
& \beta_{9} W O M_{-} R E P+\beta_{10} B R D_{-} T E N+\beta_{11} F I_{-} R E P+\beta_{12} F R M_{-} S I Z E+\beta_{13} F I N_{-} L E V+ \\
& \beta_{14} R O A+\beta_{15} M U L T \_L I S T+\beta_{16} M B+\beta_{17} V O L A T+\beta_{18} I N D+\varepsilon
\end{aligned}
$$

Finally, in the fifth model, we sought to test the combined effect of board characteristics and the level of disclosure on financing costs.

$$
\begin{gathered}
C O S T_{-} E Q / C O S T_{-} D E B T / A V G_{-} C C=\beta_{0}+\beta_{1} T R_{-} D I S C+\beta_{2} B R D_{-} S I Z E+ \\
\beta_{3} B R D_{-} I N D+\beta_{4} D U A L+\beta_{5} A U D_{-} S I Z E+\beta_{6} A U D_{-} I N D+\beta_{7} F I N_{-} M O T I V \\
+\beta_{8} B R D_{-} F R E Q+\beta_{9} A C_{-} F R E Q+\beta_{10} W O M_{-} R E P+\beta_{11} B R D \_T E N+ \\
\beta_{12} F I_{-} R E P+\beta_{13} F R M_{-} S I Z E+\beta_{14} F I N_{-} L E V+\beta_{15} R O A+ \\
\beta_{16} M U L T_{-} L I S T+\beta_{17} M B+\beta_{18} V O L A T+\beta_{19} I N D+\varepsilon
\end{gathered}
$$




\section{Results and Analysis}

\section{Descriptive Statistics}

The results presented in Table 2 below indicate that the average index of disclosure in annual reports is 0.595 and varies between 0.327 and 0.897 for a theoretical maximum of 1 (100\%), which shows differences in information disclosure policies by Canadian companies. The descriptive statistics indicate that the average financing cost by equity is $11 \%$ and varies between $1.3 \%$ and $29.9 \%$, which shows the differences in the costs of this source of financing. These results also reveal differences in debt financing costs that vary between $0.1 \%$ and $39.7 \%$ with an average cost of debt of $12.1 \%$. Finally, we observe that the average value of the weighted average cost of capital is $11.4 \%$. The results also show that the average size of boards is approximately 9 directors and varies between 4 and 16 administrators. The review of the composition of the board reveals that on average, $74.1 \%$ of directors are independent according to the Canadian National Instrument 52-110, and they carry an average $1.50 \%$ of the company's shares. Moreover, the average size of the audit committee is about 4 directors and varies between a minimum of 3 and a maximum of 6 directors. The percentage of independent directors on the audit committees varies between $33.3 \%$ and $100 \%$ with an average of $95.40 \%$. Moreover, these results show that Canadian corporate boards meet at least two times and not more than 20 times a year with an average of 9.5 meetings per year and that audit committees meet on average five times a year. These results also reveal that directors have an average tenure of 7.73 years.

Table 2

Descriptive Statistics of Continuous Variables

\begin{tabular}{|c|c|c|c|c|c|c|}
\hline Variable & $N$ & Min. & Max. & Mean & Median & Std. deviation \\
\hline$T R \_D I S C$ & 192 & 0.327 & 0.897 & 0.595 & 0.592 & 0.089 \\
\hline$C O S T \_E Q$ & 192 & 0.013 & 0.299 & 0.110 & 0.107 & 0.054 \\
\hline COST_DEBT & 192 & 0.001 & 0.397 & 0.121 & 0.068 & 0.177 \\
\hline$A V G \_C C$ & 192 & 0.014 & 0.358 & 0.114 & 0.095 & 0.074 \\
\hline BRD_SIZE & 192 & 4.000 & 16.000 & 9.171 & 9.000 & 2.372 \\
\hline BRD_IND & 192 & 0.250 & 1.000 & 0.741 & 0.750 & 0.135 \\
\hline$A U D \_S I Z E$ & 192 & 3.000 & 6.000 & 3.829 & 4.000 & 0.940 \\
\hline$A U D \_I N D$ & 192 & 0.333 & 1.000 & 0.954 & 1.000 & 0.125 \\
\hline$F I N \_M O T I V$ & 192 & 0.000 & 0.266 & 0.015 & 0.003 & 0.041 \\
\hline$B R D \_F R E Q$ & 192 & 2.000 & 20.000 & 9.500 & 8.500 & 3.798 \\
\hline$A C \_F R E Q$ & 192 & 3.000 & 11.000 & 5.366 & 5.000 & 1.568 \\
\hline BRD_TEN & 192 & 1.000 & 17.867 & 7.726 & 7.236 & 3.606 \\
\hline FRM_SIZE & 192 & 2.469 & 4.613 & 3.463 & 3.417 & 0.533 \\
\hline$R O A$ & 192 & -16.144 & 15.533 & 2.173 & 3.161 & 5.615 \\
\hline FIN_LEV & 192 & 0.002 & 0.740 & 0.254 & 0.234 & 0.164 \\
\hline$M B$ & 192 & -6.591 & 21.762 & 2.156 & 1.833 & 2.634 \\
\hline VOLAT & 192 & 0.056 & 2.625 & 1.100 & 1.050 & 0.590 \\
\hline
\end{tabular}

Note. Definitions of variables are as follows: $T R \_D I S C$ : Disclosure index; COST_EQ: Cost of equity; COST_DEBT: Cost of debt; $A V G \_C C$ : Average cost of capital; BRD_SIZE: Board size in terms of number of directors; $B R D \_I N D$ : Independence of the board of directors; $A U D \_S I Z E$ : Audit committee size; $A U D \_I N D$ : Independence of the audit committee; FIN_MOTIV: Percentage of capital owned by independent directors; $B R D \_F R E Q$ : Meeting frequency of the board of directors; $A C_{-} F R E Q$ : Meeting frequency of the audit committee; $B R D \_T E N$ : Board tenure; FRM_SIZE: Firm size (log of total assets); ROA: Return on assets; FIN_LEV: Financial leverage; $M B$ : Market-to-book ratio measuring growth opportunities; VOLAT: Volatility of stock returns. 
As indicated in Table 3, the dual structure in which the functions of CEO and chairman are separated is the majority of the Canadian companies (60.98\%). These results also show that $56.10 \%$ of the companies studied have one or more representatives of financial institutions on the board. Finally, these results reveal that women are represented in $54.88 \%$ of Canadian company boards. This result reveals that despite efforts into encouraging the presence of women on boards, they are still not represented in almost half of Canada's largest corporations.

Table 3

Descriptive Statistics of Dummy Variables

\begin{tabular}{|c|c|c|c|}
\hline Variable & & Frequency & Percentage (\%) \\
\hline \multicolumn{4}{|l|}{$D U A L$} \\
\hline Separation of functions & 0 & 117 & 60.98 \\
\hline Duality of functions (CEO is also chairman of the board) & 1 & 75 & 39.02 \\
\hline \multicolumn{4}{|l|}{$F I \_R E P$} \\
\hline No representation of financial institutions on the board & 0 & 84 & 43.90 \\
\hline Representation of financial institutions on the board & 1 & 108 & 56.10 \\
\hline \multicolumn{4}{|l|}{ WOM_REP } \\
\hline No woman is represented on the board & 0 & 87 & 45.12 \\
\hline Representation of one or more women on the board & 1 & 105 & 54.88 \\
\hline \multicolumn{4}{|l|}{ MULT_LIST } \\
\hline Company listed only on the Toronto Stock Exchange & 0 & 119 & 62.20 \\
\hline Company listed on international markets & 1 & 73 & 37.80 \\
\hline
\end{tabular}

Note. Definitions of variables are as follows: DUAL: Duality of functions of CEO and chairman of the board; FI_REP: Representation of financial institutions on the board; WOM_REP: Representation of women on the board; MULT_LIST: Multiple listing (whether the company is listed on international markets in addition to the Toronto Stock Exchange, particularly the US markets).

\section{Multivariate Analysis and Hypotheses Verification}

To analyze on one hand, the effect of board characteristics on the level of information disclosed and, on the other hand, the effect of the two groups of variables on financing costs, we test different linear regression models by controlling the effect of operational and business financial variables. Because all dependent variables are continuous, we use the model of multiple linear regression equations to estimate Models 3-7, while ensuring compliance with the conditions of application of this method of analysis ${ }^{1}$.

Analysis of disclosure level effect on business financing costs. The results of the regression models analyzing the effect of disclosure level on financing costs presented in Table 4 show satisfactory explanatory power with coefficients statistically significant. Moreover, these models indicate that $26.8 \%$ of the variation in the cost of equity, $24.3 \%$ of the variation in cost of debt, and $28.5 \%$ of the variation in the average cost of capital are explained by: the disclosure level in annual reports; firm size; profitability; growth opportunities; financial leverage; return volatility of shares; status listing and industry. The explanatory power values reflect the quality of the adjustment compared to previous studies (Lambert et al., 2007).

\footnotetext{
${ }^{1}$ The method of multiple linear regressions requires the absence of heteroscedasticity of errors problem and multicollinearity between the independent variables. On one hand, results of the asymptotic White test show that there is no problem in all heteroscedastic regression models used in our study $\left(X^{2}(\alpha, q)>\left(N^{*} R^{2}\right) c\right)$. On the other hand, the examination of the coefficient correlations between the independent variables and variance inflation factor (VIF) calculated at each regression model leads us to conclude the absence of a multicollinearity problem.
} 
Table 4

Analysis of the Disclosure Level Effect on Financing Costs

\begin{tabular}{|c|c|c|c|c|c|c|c|c|c|c|c|c|c|c|c|c|c|c|c|}
\hline \multirow{2}{*}{ Variable } & \multirow{2}{*}{$\begin{array}{l}\text { Pred. } \\
\text { sign }\end{array}$} & \multicolumn{6}{|c|}{$C O S T_{-} E Q$} & \multicolumn{6}{|c|}{$C O S T \_D E B T$} & \multicolumn{6}{|c|}{$A V G_{-} C C$} \\
\hline & & Coef. & Sig. & VIF & Coef. & Sig. & VIF & Coef. & Sig. & VIF & Coef. & Sig. & VIF & Coef. & Sig. & VIF & Coef. & Sig. & VIF \\
\hline Intercept & & $0.160^{\text {nate }}$ & 0.008 & 0.000 & $0.112^{*}$ & 0.070 & 0.000 & 0.215 & 0.218 & 0.000 & 0.120 & 0.525 & 0.000 & $0.150^{* *}$ & 0.063 & 0.000 & 0.091 & 0.253 & 0.000 \\
\hline TR_DISC & - & $-0.017^{*}$ & 0.089 & 1.641 & & & & -0.297 & 0.273 & 1.642 & & & & $-0.191^{*}$ & 0.067 & 1.64 & & & \\
\hline$T D \_S R$ & - & & & & 0.011 & 0.923 & 1.503 & & & & -0.062 & 0.562 & 1.206 & & & & -0.028 & 0.797 & 1.206 \\
\hline$T D \_F I$ & - & & & & $-0.091^{*}$ & 0.052 & 1.761 & & & & $-0.579^{*+1}$ & 0.001 & 1.272 & & & & -0.356 & 0.010 & 1.272 \\
\hline$T D \_B R D$ & - & & & & $-0.277^{* *}$ & 0.043 & 1.524 & & & & -0.039 & 0.117 & 1.475 & & & & -0.103 & 0.125 & 1.475 \\
\hline FRM_SIZE & - & $-0.218^{*}$ & 0.068 & 2.035 & $-0.270^{* *}$ & 0.023 & 1.712 & $-0.311^{* *}$ & 0.012 & 2.339 & $-0.358^{*+*}$ & 0.002 & 1.558 & $-0.297^{* *}$ & 0.013 & 2.37 & $-0.353^{*+*}$ & 0.002 & 1.914 \\
\hline$R O A$ & - & -0.033 & 0.772 & 1.541 & -0.023 & 0.840 & 2.121 & 0.306 & 0.200 & 0.826 & $0.250^{* *}$ & 0.022 & 2.361 & 0.276 & 0.156 & 0.93 & 0.235 & 0.321 & 2.358 \\
\hline$M B$ & - & -0.150 & 0.181 & 1.992 & $-0.225^{*}$ & 0.054 & 1.416 & $-0.003^{*}$ & 0.098 & 2.352 & $-0.049^{*}$ & 0.065 & 2.490 & -0.073 & 0.507 & 1.63 & -0.073 & 0.510 & 0.882 \\
\hline$F I N \_L E V$ & + & $0.179^{* *}$ & 0.043 & 2.276 & $0.192^{*}$ & 0.097 & 2.366 & $0.015^{* *}$ & 0.048 & 1.819 & $0.013^{* *}$ & 0.091 & 1.196 & $0.002^{*}$ & 0.078 & 1.307 & 0.005 & 0.161 & 1.182 \\
\hline VOLAT & + & $0.206^{* *}$ & 0.042 & 2.154 & 0.215 & 0.105 & 1.465 & 0.094 & 0.489 & 1.901 & 0.133 & 0.285 & 1.007 & $0.239^{*}$ & 0.071 & 0.899 & $0.271^{* *}$ & 0.034 & 2.422 \\
\hline MULT_LIST & - & $-0.029^{*}$ & 0.079 & 2.448 & $-0.030^{* *}$ & 0.023 & 1.464 & -0.142 & 0.215 & 0.454 & -0.014 & 0.895 & 2.481 & $-0.051^{*}$ & 0.054 & 2.276 & $-0.033^{*}$ & 0.075 & 1.762 \\
\hline$I N D 1$ & $+/-$ & 0.081 & 0.570 & 1.780 & 0.065 & 0.306 & 1.199 & -0.108 & 0.490 & 1.458 & -0.064 & 0.259 & 1.577 & -0.073 & 0.694 & 1.882 & -0.106 & 0.239 & 1.384 \\
\hline$I N D 2$ & $+/-$ & 0.170 & 0.199 & 1.541 & 0.162 & 0.234 & 1.408 & 0.016 & 0.907 & 1.365 & 0.075 & 0.557 & 1.387 & 0.132 & 0.312 & 1.815 & 0.061 & 0.638 & 2.030 \\
\hline$I N D 3$ & $+/-$ & $0.061^{*}$ & 0.062 & 1.527 & 0.047 & 0.173 & 0.970 & 0.041 & 0.772 & 0.549 & 0.026 & 0.842 & 1.573 & $0.025^{*}$ & 0.096 & 1.135 & $0.024^{*}$ & 0.086 & 1.952 \\
\hline$I N D 4$ & $+/-$ & -0.098 & 0.494 & 1.893 & 0.104 & 0.464 & 1.651 & -0.075 & 0.608 & 1.265 & -0.037 & 0.781 & 1.458 & -0.061 & 0.665 & 2.526 & -0.039 & 0.772 & 2.438 \\
\hline$N=192$ & & \multicolumn{3}{|c|}{ Adjusted $R^{2}=0.268$} & \multicolumn{3}{|c|}{ Adjusted $R^{2}=0.263$} & \multicolumn{3}{|c|}{ Adjusted $R^{2}=0.243$} & \multicolumn{3}{|c|}{ Adjusted $R^{2}=0.288$} & \multicolumn{3}{|c|}{ Adjusted $R^{2}=0.285$} & \multicolumn{3}{|c|}{ Adjusted $R^{2}=0.293$} \\
\hline
\end{tabular}

Note. ${ }^{* * *},{ }^{* *},{ }^{*}$ indicate significance at the levels of $1 \%, 5 \%$, and $10 \%$.

The detailed analysis of the effect of disclosure sub-indices, related to shareholders rights (TD_SR), financial information (TD_FI), and board characteristics ( $\left.T D \_B R D\right)$, on corporate financing costs reveals a satisfactory explanatory power of the three sub-indices compared to the overall disclosure index (TR_DISC). The results of these regressions show that $26.3 \%$ of the variation in the cost of equity, $28.8 \%$ of the variation in the cost of debt, and $29.3 \%$ of the variation of the average cost of capital, are explained by disclosure sub-indices and control variables.

The analysis of the results reveals a negative and significant effect of the disclosure level on the cost of equity and the weighted average cost of capital, which confirms hypothesis H1. The thorough analysis of the level of disclosure across the three disclosure sub-indices showed a non-significant negative effect of the level of disclosed information on the shareholders rights and the ownership structure on the cost of debt and the weighted average cost of capital. Moreover, these results show a negative and significant effect of the level of financial information disclosure on the costs of financing by equity capital and debt, as well as the average cost of capital. The sub-index related to information disclosure on corporate governance and board structure in particular has a negative and significant effect on the cost of equity. These results highlight the importance of accounting and financial data as well as information on corporate governance for investors and creditors in determining the performance and the risk premium required when granting funding to companies.

Finally, these results reveal on one hand, a negative and significant effect of the size of the company, its growth opportunities, and its multi-listing status on financing costs by equity capital and debt as well as on the average cost of capital, and on the other hand, a positive and significant effect of financial leverage and risk level on the financing costs. 
Analysis of board characteristics effect on the level of disclosure. The results of the regression models analyzing the effect of board characteristics on the level of information disclosed in the annual reports presented in Table 5 show a satisfactory explanatory power with $F$-statistic significant at the $1 \%$ level. These results indicate that $42.5 \%$ of the variation in the level of disclosed information is explained by board characteristics and the control variables. Furthermore, the analysis of the effect of board characteristics on the three disclosure sub-indices reveals a satisfactory explanatory power with statistically significant $F$-statistics. The results of these regressions show the respective values of adjusted $R$ squared, indicating that $22.8 \%$ of the variation in the disclosure level of information regarding the shareholders rights, $52.1 \%$ of the variation in the disclosure level of financial information, and 39\% of the variation in the disclosure level of information regarding board structure are explained by board characteristics and the control variables.

Table 5

Analysis of the Effect of Board Characteristics on Disclosure Level

\begin{tabular}{|c|c|c|c|c|c|c|c|c|c|c|c|c|c|}
\hline \multirow{2}{*}{ Variable } & \multirow{2}{*}{$\begin{array}{l}\text { Pred. } \\
\text { sign }\end{array}$} & \multicolumn{3}{|c|}{$T R \_D I S C$} & \multicolumn{3}{|c|}{$T D \_S R$} & \multicolumn{3}{|c|}{$T D \_F I$} & \multicolumn{3}{|c|}{$T D \_B R D$} \\
\hline & & Coef. & Sig. & VIF & Coef. & Sig. & VIF & Coef. & Sig. & VIF & Coef. & Sig. & VIF \\
\hline Intercept & & $0.203^{*}$ & 0.089 & 0.000 & 0.143 & 0.439 & 0.000 & $0.505^{* *}$ & 0.021 & 0.000 & $0.312^{* *}$ & 0.045 & 0.000 \\
\hline BRD_SIZE & + & $0.272^{*}$ & 0.099 & 0.808 & $0.262^{* *}$ & 0.016 & 0.744 & $0.033^{*}$ & 0.082 & 1.215 & $0.096^{*}$ & 0.083 & 1.356 \\
\hline BRD_IND & + & $0.064^{*}$ & 0.061 & 1.461 & 0.089 & 0.544 & 1.606 & $0.266^{* *}$ & 0.024 & 2.482 & $0.056^{*}$ & 0.067 & 1.073 \\
\hline$D U A L$ & - & -0.100 & 0.398 & 1.517 & -0.082 & 0.552 & 2.393 & 0.026 & 0.807 & 1.804 & -0.005 & 0.967 & 0.880 \\
\hline$A U D \_S I Z E$ & + & $0.451^{*}$ & 0.074 & 2.425 & 0.032 & 0.843 & 1.913 & 0.010 & 0.239 & 1.470 & $0.223^{* *}$ & 0.012 & 1.818 \\
\hline$A U D \_I N D$ & + & 0.091 & 0.140 & 0.763 & 0.095 & 0.554 & 2.078 & 0.091 & 0.469 & 2.262 & 0.086 & 0.544 & 2.445 \\
\hline FIN_MOTIV & + & $-0.195^{*}$ & 0.087 & 2.116 & -0.014 & 0.913 & 1.953 & $-0.272^{* * *}$ & 0.010 & 1.759 & -0.136 & 0.241 & 1.805 \\
\hline BRD_FREQ & + & $0.218^{*}$ & 0.065 & 1.242 & 0.009 & 0.947 & 2.373 & $0.268^{* *}$ & 0.014 & 2.148 & $0.200^{*}$ & 0.100 & 1.944 \\
\hline$A C \_F R E Q$ & + & 0.032 & 0.771 & 0.982 & 0.026 & 0.839 & 2.138 & $0.097^{* *}$ & 0.033 & 2.533 & 0.077 & 0.492 & 1.395 \\
\hline BRD_TEN & + & $0.102^{* *}$ & 0.040 & 1.212 & 0.026 & 0.855 & 0.818 & $0.095^{*}$ & 0.094 & 1.515 & 0.008 & 0.951 & 1.962 \\
\hline$F I \_R E P$ & + & $0.040^{*}$ & 0.075 & 0.777 & 0.073 & 0.617 & 1.222 & 0.075 & 0.516 & 1.157 & $0.077^{*}$ & 0.055 & 0.689 \\
\hline WOM_REP & + & $0.080^{*}$ & 0.055 & 1.618 & 0.121 & 0.383 & 1.750 & 0.072 & 0.511 & 0.883 & $0.054^{*}$ & 0.066 & 1.037 \\
\hline$F R M \_S I Z E$ & + & $0.208^{* *}$ & 0.015 & 1.456 & $0.094^{*}$ & 0.0575 & 2.561 & $0.159^{* *}$ & 0.023 & 1.985 & $0.131^{* *}$ & 0.038 & 2.479 \\
\hline$R O A$ & $+/-$ & 0.016 & 0.885 & 2.384 & -0.098 & 0.457 & 2.356 & 0.127 & 0.222 & 1.521 & 0.054 & 0.642 & 2.568 \\
\hline$M B$ & + & $0.343^{*}$ & 0.078 & 2.582 & 0.020 & 0.884 & 0.812 & 0.003 & 0.980 & 1.039 & $0.031^{*}$ & 0.080 & 1.500 \\
\hline$F I N \_L E V$ & - & 0.082 & 0.459 & 1.238 & 0.013 & 0.188 & 1.859 & 0.008 & 0.939 & 1.140 & 0.264 & 0.102 & 1.679 \\
\hline$M U L T \_L I S T$ & + & $0.095^{*}$ & 0.071 & 1.652 & 0.052 & 0.694 & 1.871 & $0.094^{* *}$ & 0.037 & 2.026 & 0.084 & 0.473 & 0.951 \\
\hline$I N D 1$ & $+/-$ & -0.066 & 0.608 & 1.708 & $-0.103^{*}$ & 0.093 & 0.778 & $-0.092^{*}$ & 0.070 & 1.215 & -0.073 & 0.743 & 2.010 \\
\hline IND2 & $+/-$ & 0.276 & 0.442 & 2.500 & $0.323^{* *}$ & 0.043 & 1.865 & $0.307^{* *}$ & 0.015 & 2.211 & 0.164 & 0.241 & 1.634 \\
\hline IND3 & $+/-$ & 0.228 & 0.106 & 1.649 & 0.103 & 0.524 & 1.866 & 0.178 & 0.165 & 2.590 & 0.159 & 0.272 & 0.881 \\
\hline IND4 & $+/-$ & -0.066 & 0.608 & 1.353 & 0.165 & 0.271 & 2.478 & -0.008 & 0.943 & 0.859 & 0.068 & 0.607 & 0.871 \\
\hline$N=192$ & & \multicolumn{3}{|c|}{ Adjusted $R^{2}=0.225$} & \multicolumn{3}{|c|}{ Adjusted $R^{2}=0.238$} & \multicolumn{3}{|c|}{ Adjusted $R^{2}=0.307$} & \multicolumn{3}{|c|}{ Adjusted $R^{2}=0.316$} \\
\hline
\end{tabular}

Note. ${ }^{*},{ }^{*}$ indicate significance at the levels of $1 \%, 5 \%$, and $10 \%$.

The results of the regression model analyzing the effect of board characteristics on the overall disclosure level show a positive and statistically significant effect of the board size, the independence of its directors, the size of the audit committee, the board tenure, the meeting frequency, and the percentage of capital held by the independent directors on the level of information disclosed by the companies in their annual reports. This confirms hypotheses H2.1, H2.2, H2.5, and H2.8 respectively. These results also show that boards where women and financial institutions are represented globally disclose more information. In addition, the results found show that larger companies with strong growth opportunities and listed on foreign stock-exchange markets disclose significantly more information in their annual reports. 
Thorough examination of the sub-components of the overall disclosure index (TR_DISC) shows that only the size of the board positively and significantly affects the amount of information on shareholders rights and ownership structure. Furthermore, the size of the board, the independence of its directors, its tenure, the frequency of its meetings, and its audit committee have a positive and statistically significant impact on the reporting of accounting and financial information by companies in their annual reports. The results also show that the participation of independent directors on firm's capital significantly reduces the extent of accounting and financial information disclosure. These results show that larger companies listed on foreign stock-exchange markets and belonging to the materials sector disclose more accounting and financial information in their annual reports. Finally, this analysis reveals that larger and independent boards, which meet more often, having a larger audit committee in which women and financial institutions are represented, disclose more information on the structure and process of the board. The communication of such information is positively affected by the size of the company and its growth opportunities.

Table 6

Analysis of the Effect of Board Characteristics on Financing Costs

\begin{tabular}{|c|c|c|c|c|c|c|c|c|c|c|}
\hline \multirow{2}{*}{ Variable } & \multirow{2}{*}{$\begin{array}{l}\text { Pred. } \\
\text { sign }\end{array}$} & \multicolumn{3}{|c|}{ COST_EQ } & \multicolumn{3}{|c|}{ COST_DEBT } & \multicolumn{3}{|c|}{$A V G_{-} C C$} \\
\hline & & Coef. & Sig. & VIF & Coef. & Sig. & VIF & Coef. & Sig. & VIF \\
\hline Intercept & & $0.016^{* *}$ & 0.046 & 0.000 & $0.006^{* *}$ & 0.020 & 0.000 & $0.027^{* *}$ & 0.019 & 0.000 \\
\hline BRD_SIZE & - & $-0.082^{*}$ & 0.061 & 1.645 & $-0.055^{*}$ & 0.075 & 1.516 & $-0.134^{*}$ & 0.072 & 0.762 \\
\hline BRD_IND & - & -0.224 & 0.194 & 2.111 & -0.015 & 0.918 & 0.743 & -0.181 & 0.182 & 2.277 \\
\hline$D U A L$ & + & 0.037 & 0.763 & 2.100 & 0.019 & 0.889 & 0.691 & 0.064 & 0.612 & 0.583 \\
\hline$A U D \_S I Z E$ & - & $-0.166^{* *}$ & 0.027 & 0.740 & $-0.267^{*}$ & 0.098 & 1.367 & -0.213 & 0.166 & 1.592 \\
\hline$A U D \_I N D$ & - & -0.156 & 0.287 & 1.445 & -0.055 & 0.726 & 2.189 & -0.132 & 0.378 & 1.413 \\
\hline FIN_MOTIV & - & -0.059 & 0.196 & 0.891 & $-0.199^{*}$ & 0.085 & 0.678 & -0.104 & 0.386 & 1.058 \\
\hline$B R D \_F R E Q$ & - & -0.119 & 0.330 & 1.723 & -0.079 & 0.154 & 1.359 & -0.017 & 0.295 & 2.250 \\
\hline$A C \_F R E Q$ & - & -0.078 & 0.150 & 2.219 & -0.140 & 0.258 & 2.034 & -0.076 & 0.519 & 1.405 \\
\hline BRD_TEN & - & $-0.088^{*}$ & 0.100 & 1.556 & $-0.198^{* *}$ & 0.015 & 1.839 & $-0.239^{*}$ & 0.071 & 2.124 \\
\hline$F I \_R E P$ & - & $-0.103^{* *}$ & 0.042 & 2.078 & $-0.135^{* *}$ & 0.034 & 1.125 & $-0.194^{*}$ & 0.088 & 0.796 \\
\hline WOM_REP & - & $-0.173^{*}$ & 0.068 & 0.539 & -0.072 & 0.589 & 0.740 & -0.065 & 0.161 & 1.541 \\
\hline FRM_SIZE & - & $-0.156^{* *}$ & 0.029 & 1.343 & $-0.278^{*}$ & 0.083 & 1.739 & $-0.229^{*}$ & 0.083 & 1.662 \\
\hline$R O A$ & - & -0.027 & 0.823 & 1.891 & 0.028 & 0.134 & 2.179 & 0.023 & 0.265 & 1.466 \\
\hline$M B$ & - & -0.149 & 0.193 & 1.315 & -0.065 & 0.160 & 2.006 & -0.016 & 0.894 & 0.846 \\
\hline FIN_LEV & + & $0.199^{*}$ & 0.092 & 0.679 & $0.026^{*}$ & 0.085 & 1.769 & $0.093^{*}$ & 0.086 & 0.954 \\
\hline$V O L A T$ & + & $0.018^{*}$ & 0.084 & 0.790 & 0.066 & 0.191 & 2.028 & $0.094^{* *}$ & 0.042 & 1.324 \\
\hline MULT_LIST & - & $-0.102^{*}$ & 0.085 & 0.792 & -0.073 & 0.563 & 1.314 & $-0.162^{*}$ & 0.082 & 2.042 \\
\hline$I N D 1$ & $+/-$ & 0.054 & 0.378 & 1.127 & -0.173 & 0.216 & 2.016 & -0.074 & 0.401 & 1.191 \\
\hline IND2 & $+/-$ & 0.148 & 0.308 & 2.199 & 0.015 & 0.922 & 1.251 & 0.049 & 0.174 & 0.751 \\
\hline IND3 & $+/-$ & 0.171 & 0.163 & 1.710 & 0.015 & 0.926 & 1.220 & $0.023^{*}$ & 0.088 & 1.402 \\
\hline IND4 & $+/-$ & -0.090 & 0.550 & 2.170 & -0.163 & 0.314 & 0.499 & -0.129 & 0.403 & 0.732 \\
\hline$N=192$ & & \multicolumn{3}{|c|}{ Adjusted $R^{2}=0.378$} & \multicolumn{3}{|c|}{ Adjusted $R^{2}=0.289$} & \multicolumn{3}{|c|}{ Adjusted $R^{2}=0.353$} \\
\hline
\end{tabular}

Note. ${ }^{* * *},{ }^{* * *}{ }^{*}$ indicate significance at the levels of $1 \%, 5 \%$, and $10 \%$.

Analysis of board characteristics effect on financing costs. The analysis of the results of regression models (see Table 6 above) examining the effect of board characteristics on the costs of financing shows satisfactory explanatory powers with $F$-statistics significant at the $1 \%$ level. The adjusted $R$ squared values indicate that $37.8 \%$ of the variation in the cost of equity, $28.9 \%$ of the variation in the cost of debt, and $35.3 \%$ 
of the variation in the average cost of capital are explained by board characteristics and variables of control. The results of this analysis show that the size of the board, its tenure, and size of its audit committee have a negative and statistically significant effect on the cost of equity. These results also show that boards of directors where women and financial institutions are represented allow reducing the cost of financing, thus confirming the hypothesis H3.2, H3.5, H3.6, H3.7, and H3.9. Furthermore, the results found reveal that the size of the company and its listing status on foreign stock-exchange markets have a negative and statistically significant effect on the cost of equity capital and that the level of financial leverage of the company and the return volatility of its shares have a positive and significant impact on this cost of financing.

Examination of the results of the model analyzing the effect of board characteristics on the cost of debt (see Table 6) shows that larger boards with greater ownership of independent directors, larger auditing committees and experienced and competent directors and where financial institutions are represented allow reducing the cost of financing by debt. This analysis also shows that larger companies listed on foreign stock-exchange markets profit lower cost of debt.

Finally, the review of the results of the regression model analyzing the effect of board characteristics on the average cost of capital shows that larger boards, composed of qualified and experienced directors and in which financial institutions are represented, have a negative and significant effect on the cost of funding. Moreover, these results show that larger companies listed on foreign stock-exchange markets, with lower financial leverage, lower returns volatility, and not belonging to the manufacturing sector, enjoy lower average cost of capital.

Analysis of combined effect of board characteristics and disclosure transparency on business financing costs. The results (see Table 7) show higher explanatory power when board characteristics are associated with the levels of disclosure transparency $\left(T R \_D I S C\right)$ higher than when these variables are analyzed separately in the explanation of financing costs. Indeed, the explanatory powers found are higher when integrating the combined effect of board characteristics and disclosure transparency and when the effect of these variables is analyzed individually. Thus, variations in corporate financing costs by equity capital and debt can be better explained through the combined analysis of factors related to corporate governance attributes and disclosure level. As a result, companies wishing to benefit from lower financing costs should, on one hand, have an effective corporate governance system promoted by a board of directors whose characteristics meet the requirements and rules of good governance, and on the other hand, have a transparent information disclosure policy that allows extensive and detailed disclosure. The results of the regression model analyzing the combined effect of board characteristics and the disclosure level and their interaction on the cost of equity capital (see Table 7) show a negative and significant effect of the board size, its tenure, the size of its audit committee, the representation of women and financial institutions among its directors, and the overall level of the disclosure on this cost of capital. These results also show that larger companies with stronger growth opportunities, a lower financial leverage, and listed on foreign stock-exchange markets benefit from lower costs of equity.

In-depth analysis of the combined effect of corporate governance attributes and disclosure level through the three disclosure sub-indices on the cost of equity reveals a greater explanatory power (50.7\%) than that associated with the overall level of disclosure TR_DISC (48.1\%). This analysis allows the high lighting of the negative and significant effect on the level of information disclosed about board characteristics (TD_BRD), on the cost of capital particularly when combined with strong and effective boards whose characteristics meet the rules and governance best practices. 
Table 7

Analysis of the Effect of Board Characteristics and Disclosure Level on Financing Costs

\begin{tabular}{|c|c|c|c|c|c|c|c|c|c|c|c|c|c|}
\hline \multirow{2}{*}{ Variable } & \multirow{2}{*}{$\begin{array}{l}\text { Pred. } \\
\text { sign }\end{array}$} & \multicolumn{4}{|c|}{ COST_EQ } & \multicolumn{4}{|c|}{ COST_DEBT } & \multicolumn{4}{|c|}{$A V G_{-} C C$} \\
\hline & & Coef. & Sig. & Coef. & Sig. & Coef. & Sig. & Coef. & Sig. & Coef. & Sig. & Coef. & Sig. \\
\hline Intercept & & $0.015^{*}$ & 0.070 & $0.023^{*}$ & 0.061 & $0.024^{*}$ & 0.059 & $0.036^{*}$ & 0.068 & $0.021^{* *}$ & 0.047 & $0.034^{*}$ & 0.056 \\
\hline BRD_SIZE & - & $-0.084^{*}$ & 0.061 & $-0.069^{*}$ & 0.073 & $-0.048^{*}$ & 0.078 & $-0.039^{* *}$ & 0.045 & $-0.129^{* *}$ & 0.043 & $-0.132^{* * *}$ & 0.039 \\
\hline BRD_IND & - & -0.219 & 0.104 & $-0.135^{*}$ & 0.094 & -0.030 & 0.983 & -0.041 & 0.763 & -0.168 & 0.210 & $-0.105^{*}$ & 0.067 \\
\hline$D U A L$ & + & 0.045 & 0.719 & 0.027 & 0.541 & 0.012 & 0.927 & 0.027 & 0.609 & 0.043 & 0.736 & 0.056 & 0.821 \\
\hline AUD_SIZE & - & $-0.164^{* *}$ & 0.028 & $-0.156^{* *}$ & 0.033 & $-0.275^{*}$ & 0.082 & $-0.183^{*}$ & 0.079 & -0.218 & 0.152 & -0.187 & 0.166 \\
\hline$A U D \_I N D$ & - & -0.163 & 0.273 & -0.164 & 0.211 & -0.079 & 0.607 & -0.064 & 0.518 & -0.149 & 0.317 & -0.126 & 0.254 \\
\hline$F I N \_M O T I V$ & - & -0.020 & 0.187 & -0.041 & 0.306 & $-0.145^{* *}$ & 0.049 & $-0.131^{* *}$ & 0.042 & -0.065 & 0.593 & -0.077 & 0.643 \\
\hline$B R D \_F R E Q$ & - & -0.135 & 0.285 & -0.098 & 0.217 & -0.017 & 0.190 & -0.023 & 0.127 & -0.044 & 0.293 & -0.052 & 0.309 \\
\hline$A C \_F R E Q$ & - & -0.076 & 0.151 & -0.085 & 0.421 & $-0.146^{* *}$ & 0.023 & $-0.104^{* *}$ & 0.036 & -0.081 & 0.488 & -0.068 & 0.396 \\
\hline$B R D \_T E N$ & - & $-0.074^{*}$ & 0.095 & $-0.093^{*}$ & 0.089 & $-0.226^{*}$ & 0.097 & $-0.184^{*}$ & 0.087 & $-0.259^{*}$ & 0.051 & $-0.261^{*}$ & 0.075 \\
\hline$F I \_R E P$ & - & $-0.178^{*}$ & 0.059 & $-0.101^{*}$ & 0.067 & $-0.150^{*}$ & 0.070 & $-0.164^{* *}$ & 0.048 & $-0.181^{*}$ & 0.052 & $-0.162^{*}$ & 0.059 \\
\hline WOM_REP & - & $-0.100^{* *}$ & 0.045 & $-0.094^{* *}$ & 0.039 & -0.015 & 0.286 & -0.027 & 0.319 & -0.071 & 0.193 & -0.084 & 0.162 \\
\hline$T R \_D I S C$ & - & $-0.074^{*}$ & 0.059 & & & $-0.082^{*}$ & 0.095 & & & $0.202^{* *}$ & 0.045 & & \\
\hline$T D \_S R$ & - & & & 0.023 & 0.651 & & & -0.049 & 0.301 & & & -0.084 & 0.601 \\
\hline$T D \_F I$ & - & & & -0.078 & 0.133 & & & $-0.294^{* *}$ & 0.017 & & & $-0.205^{*}$ & 0.074 \\
\hline$T D \_B R D$ & - & & & $-0.157^{* * * *}$ & 0.009 & & & $-0.031^{*}$ & 0.056 & & & $-0.108^{* *}$ & 0.039 \\
\hline FRM_SIZE & - & $-0.170^{* *}$ & 0.026 & $-0.134^{* *}$ & 0.032 & $-0.332^{* *}$ & 0.038 & $-0.287^{* *}$ & 0.042 & $-0.267^{*}$ & 0.083 & $-0.280^{*}$ & 0.090 \\
\hline$R O A$ & - & -0.027 & 0.822 & -0.011 & 0.562 & 0.028 & 0.129 & 0.031 & 0.207 & 0.023 & 0.162 & 0.041 & 0.173 \\
\hline$M B$ & - & -0.156 & 0.179 & -0.104 & 0.127 & -0.039 & 0.175 & -0.042 & 0.123 & -0.034 & 0.770 & -0.056 & 0.791 \\
\hline FIN_LEV & + & $0.201^{* *}$ & 0.017 & $0.183^{*}$ & 0.056 & $0.019^{*}$ & 0.088 & $0.013^{*}$ & 0.064 & $0.179^{*}$ & 0.089 & $0.108^{*}$ & 0.056 \\
\hline VOLAT & + & 0.018 & 0.217 & 0.049 & 0.328 & 0.051 & 0.599 & 0.072 & 0.503 & $0.105^{* *}$ & 0.047 & $0.114^{*}$ & 0.073 \\
\hline$M U L T \_L I S T$ & - & $-0.088^{*}$ & 0.087 & $-0.103^{*}$ & 0.096 & -0.061 & 0.621 & -0.056 & 0.731 & -0.154 & 0.120 & $-0.112^{*}$ & 0.100 \\
\hline$I N D 1$ & $+/-$ & 0.047 & 0.407 & 0.075 & 0.541 & -0.109 & 0.478 & -0.114 & 0.426 & -0.069 & 0.724 & -0.089 & 0.681 \\
\hline$I N D 2$ & $+/-$ & 0.128 & 0.393 & 0.141 & 0.302 & 0.090 & 0.562 & 0.092 & 0.521 & 0.052 & 0.724 & 0.063 & 0.707 \\
\hline$I N D 3$ & $+/-$ & 0.054 & 0.722 & 0.061 & 0.893 & 0.049 & 0.758 & 0.043 & 0.834 & $0.023^{*}$ & 0.088 & $0.034^{*}$ & 0.058 \\
\hline$I N D 4$ & $+/-$ & -0.094 & 0.538 & -0.072 & 0.147 & -0.176 & 0.265 & -0.145 & 0.303 & -0.138 & 0.365 & -0.105 & 0.296 \\
\hline$N=192$ & & Adj. $R^{2}$ & $=0.481$ & Adj. $R^{2}$ & $=0.507$ & Adj. $R^{2}$ & $=0.385$ & Adj. $R^{2}$ & $=0.429$ & Adj. $R^{2}$ & $=0.436$ & Adj. $R^{2}$ & $=0.472$ \\
\hline
\end{tabular}

The analysis of the results of the model examining the combined effect of board characteristics and disclosure transparency on the cost of debt shows that larger boards composed of qualified and experienced directors, with larger audit committee meeting more regularly, and in which financial institutions are represented among its members, associated with higher levels of information disclosure in annual reports allow significantly reducing the cost of financing by debt. These results thus show that firms should not be limited to a broader level of disclosure or more effective boards to reduce the estimated risk premium required by shareholders as well as creditors. They must ensure the overall quality of their corporate governance system through an effective board complemented by transparent disclosure. This analysis also shows that larger companies with reduced financial leverage, lower asset returns, and stronger growth opportunities benefit from reduced cost of debt. Further analysis of the combined effect of corporate governance attributes and disclosure levels in the three sub-indices on the cost of debt reveals a higher explanatory power (42.9\%) than that associated with the overall disclosure level (38.5\%). This analysis allows the highlighting of negative and significant effect on the level of information disclosed regarding board characteristics $\left(T D_{-} B R D\right)$ and financial data $\left(T D \_F I\right)$ on the cost of debt, particularly when combined with board of directors whose characteristics meet the rules and governance best practices. 
Finally, the results reveal that larger boards composed of qualified and experienced directors, in which women and financial institutions are represented, and who have larger audit committees allow reducing more significantly the average cost of capital when combined with significantly higher disclosure levels. These results also show that smaller companies with higher financial leverage, higher profitability, and higher risk pay higher average costs of capital. Once again, the thorough analysis of the three disclosure sub-indices shows a negative and significant effect of board size, board independence, board tenure, and financial institutions' representation on the board on the average cost of capital particularly when these characteristics are associated with high levels of information disclosure regarding corporate governance attributes and financial information. Thus, companies with effective boards, associated with better transparency in disclosure, enjoy lower costs of external financing (equity and debt). Indeed, boards whose characteristics meet the requirements of good governance promote better control and greater disclosure transparency through a higher level of information disclosed on corporate governance attributes, to significantly reduce the costs of financing by equity capital and debt, and consequently, the average cost of capital. These results confirm the general hypothesis $\mathrm{H} 4$ that the effect of board characteristics on the company's financing costs is enhanced by a more transparent disclosure.

\section{Conclusion and Discussion}

\section{Summary of Research Results}

This research analyzes the effect of board characteristics and disclosure transparency of Canadian corporations on financing costs. The obtained results reveal that larger boards, composed of competent and experienced directors including those where women are represented, in which the functions of the chairman and CEO are separated, which have a large, independent audit committee, and which meet more regularly, allow significantly improving the transparency of disclosure through a broader level and detailed information. In addition, these results show that larger boards composed of experienced and qualified directors, with greater ownership of independent directors, with larger audit committees, and in which financial institutions and women are represented can significantly reduce the financing costs by equity capital and debt as well as the average cost of capital. The results also show the importance of the disclosure level in determining financing costs by equity and debt. Indeed, the results indicate the existence of a complementary relationship between the two attributes of transparency and stress the importance of this interaction in explaining the costs of corporate financing. In particular, the results indicate that boards whose characteristics meet the requirements of good governance promote efficient control of management and accounting and financial reporting process, and consequently allow greater disclosure transparency, together leading to significantly reduced costs of financing by debt as well as by equity capital.

\section{Scientific Contributions}

The results help enrich the financial and accounting literature by showing the importance of board characteristics, as the primary governance mechanism in the determination of disclosure transparency and corporate financing costs by both equity and debt. This research also highlights the importance of the complementary relationship between disclosure level and board characteristics in explaining changes in financing costs for Canadian businesses. 


\section{Practical Implications}

Our results reveal that companies are encouraged to strengthen the attributes of their boards of directors to maximize their efficiencies and ensure more transparent disclosure which enables them to significantly reduce their financing costs. In addition, if Canadian companies are looking to reduce the financing costs, by both equity and debt in this difficult economic and financial situation, they have to control their governance system in general, their boards and their disclosure policies in particular. Indeed, they must control the characteristics of their boards and give greater importance to transparency in disclosure by completing a comprehensive communication on corporate governance attributes with extended financial information.

\section{Study Limitations and Future Research Paths}

This research integrates some key features of the board, but not all of them. To this end, future research may broaden and deepen the research framework incorporating other features of the board to better identify the determinants of efficiency of this central governance mechanism and its implications on transparency in disclosure and financing costs as well as other measures of performance. Moreover, it would be interesting to incorporate the influence of differences in institutional environments in explaining the levels of transparency in disclosure and corporate financing costs through an international comparison.

\section{References}

Adams, R. B., \& Ferreira, D. (2007). A theory of friendly boards. Journal of Finance, 62(1), 217-250.

Adams, R. B., \& Ferreira, D. (2009). Women in the boardroom and their impact on governance and performance. Journal of Financial Economics, 94(2), 291-309.

Adams, R. B., \& Mehran, H. (2002). Board structure and banking firm performance. Working Paper, Federal Reserve Bank of New York.

Ahmed, L., \& Courtis, J. K. (1999). Associations between corporate characteristics and disclosure levels in annual reports: A meta-analysis. British Accounting Review, 31(1), 35-61.

Alexandre, H., \& Paquerot, M. (2000). Efficacité des structures de contrôle et enracinement des dirigeants. Finance Contrôle Stratégie, 3(2), 5-29.

Anderson, R. C., Mansi, S. A., \& Reeb, D. M. (2004). Board characteristics, accounting report integrity, and the cost of debt. Journal of Accounting and Economics, 37(3), 315-342.

Beasley, M. S. (1996). An empirical analysis of the relation between the board of director composition and financial statement fraud. The Accounting Review, 71(4), 443-465.

Blom, J., \& Schauten, M. B. J. (2008). Corporate governance and the cost of debt. In J. O. Soares (Ed.), New developments in financial modeling (pp. 116-145). Cambridge Scholars Publishing.

Blue Ribbon Committee Report. (1999). Report and recommendations of the Blue Ribbon Committee on improving the effectiveness of corporate audit committees. New York, NY: New York Stock Exchange.

Botosan, C. (1997). Disclosure level and the cost of equity capital. The Accounting Review, 72(3), 323-349.

Chen, K., Chen, Z., \& Wei, J. (2009). Legal protection of investors, corporate governance, and the cost of equity capital. Journal of Corporate Finance, 15(3), 273-289.

Coles, J. L., Daniel, N. D., \& Naveen, L. (2008). Boards: Does one size fit all? Journal of Financial Economics, 87(2), 329-356.

Cremers, K. J. M., \& Nair, V. B. (2005). Governance mechanisms and equity prices. Journal of Finance, 60(6), 2859-2894.

De Andres, P., Azofra, V., \& Lopez, F. (2005). Corporate boards in OECD countries: Size, composition, functioning and effectiveness. Corporate Governance: An International Review, 13(2), 197-210.

Diamond, D. W., \& Verrecchia, R. E. (1991). Disclosure, liquidity, and the cost of capital. Journal of Finance, 46(4), $1325-1359$.

Easley, D., \& O’Hara, M. (2004). Information and the cost of capital. Journal of Finance, 59(4), 1553-1583.

Easton, P. D. (2004). PE ratios, PEG ratios, and estimating the implied expected rate of return on equity capital. The Accounting Review, 79(1), 73-95. 
Eisenberg, T., Sundgren, S., \& Wells, M. T. (1998). Larger board size and decreasing firm value in small firms. Journal of Financial Economics, 48(1), 35-54.

Fama, E. F., \& Jensen, M. C. (1983). Separation of ownership and control. Journal of Law and Economics, 26(2), 301-325.

Francis, J., Nanda, D., \& Olsson, P. (2008). Voluntary disclosure, earnings quality, and cost of capital. Journal of Accounting Research, 46(1), 53-99.

Gompers, P. A., Ishii, J. L., \& Metrick, A. (2003). Corporate governance and equity prices. Quarterly Journal of Economics, $118(1), 107-156$.

Gouiaa, R., \& Zéghal, D. (2009). The effect of the board of directors' characteristics on the financing strategies of French companies. Journal of International Management Studies, 4(2), 16-27.

Harford, J., Mansi, S. A., \& Maxwell, W. F. (2008). Corporate governance and firm cash holdings in the US. Journal of Financial Economics, 87(3), 535-555.

Harris, M., \& Raviv, A. (2008). A theory of board control and size. Review of Financial Studies, 21(4), 1797-1832.

Healy, P. M., \& Palepu, K. G. (2001). Information asymmetry, corporate disclosure, and the capital markets: A review of the empirical disclosure literature. Journal of Accounting and Economics, 31(1-3), 405-440.

Jensen, M. C., \& Meckling, W. H. (1976). Theory of the firm: Managerial behavior, agency costs and ownership structure. Journal of Financial Economics, 3(4), 305-360.

Klein, A. (2002). Audit committee, board of director characteristics, and earnings management. Journal of Accounting and Economics, 33(3), 375-400.

Klock, M. S., Mansi, S. A., \& Maxwell, W. F. (2005). Does corporate governance matter to bondholders? Journal of Financial and Quantitative Analysis, 40(4), 693-719.

Kroszner, R. S., \& Strahan, P. E. (2001). Bankers on boards: Monitoring, conflicts of interest, and lender liability. Journal of Financial Economics, 62(3), 415-452.

Lambert, R., Leuz, C., \& Verrecchia, R. E. (2007). Accounting information, disclosure, and the cost of capital. Journal of Accounting Research, 45(2), 385-420.

Macey, J. R., \& O’Hara, M. (2003). The corporate governance of banks. Economic Policy Review, 9(1), 91-107.

Merton, R. C. (1987). A simple model of capital market equilibrium with incomplete information. Journal of Finance, 42(3), 483-510.

Pearce, J. A., \& Zahra, S. A. (1992). Board composition from a strategic contingency perspective. Journal of Management Studies, 29(4), 411-438.

Raghunandan, K., \& Rama, D. V. (2007). Determinants of audit committee diligence. Accounting Horizons, 21(3), $265-279$.

Vafeas, N. (1999). Board meeting frequency and firm performance. Journal of Financial Economics, 53(1), 113-142.

Verrecchia, R. E. (1983). Discretionary disclosure. Journal of Accounting \& Economics, 5, 179-194.

Xie, B., Davidson, W. N., \& DaDalt, P. J. (2003). Earnings management and corporate governance: The role of the board and the audit committee. Journal of Corporate Finance, 9(3), 295-316.

Yermack, D. (2004). Remuneration, retention, and reputation incentives for outside directors. Journal of Finance, 59(4), 2281-2308. 